PRZEMYSŁaW ŚLESZYŃSKI

Polish Academy of Sciences, Institute of Geography and Spatial Organization, Warsaw, Poland

\title{
Headquarters of Large Enterprises in the Spatial Structure of Major Polish Cities
}

\begin{abstract}
The paper is based on the author's monograph (Śleszyński, 2008). It presents the analysis of enterprise headquarters' locations in eight largest Polish cities (Warsaw, Szczecin, The Tricity [Gdańsk-Gdynia-Sopot], Poznań, Łódź, Wrocław, Katowice and Krakow). The study primarily involved data from the Hoppenstedt Bonnier database for the year 2004, concerning 3810 entities whose overall revenue exceeded the minimum of 15.6 million PLN. The businesses were analysed in terms of their location with respect to the city centre, as well as the differentiation of revenues, line of business and ownership structure. The analyses helped in the formulation of the basic regularities of the location distribution. For instance, it was found that spatial concentration is most significant in the case of the largest enterprises, the public sector and more advanced businesses, particularly high-order services. The location of large company headquarters, as well as their mutual connections, performs one of the key roles (or even the most important one) in the development of Central Business Districts in Polish cities during transformation.
\end{abstract}

Key words: business location; CBD; economic control functions; enterprise; geography of enterprises; internal city space; Poland; spatial concentration

\section{INTRODUCTION}

Business location in urbanised areas has been the subject of many studies. This is due to the fact that enterprises, according to functional ranking, are located in larger urban centres. Therefore, researchers analysing the location of businesses in space must naturally focus on urbanised areas, studied by various scientific disciplines. Moreover, the development of urbanised areas is highly dependent on the concentration of business activity, as it results from the fundamental principles of the evolution of social and economic space.

Research on the location of enterprises within urban centres, though quite advanced globally, was not too frequent in Poland. This is obviously the consequence of this type of analyses being limited before 1989 due to a different political and economic system, as well as the practical lack of influence of land rent on business location (Węcławowicz, 1996; Domański, 1997). Moreover, the issue of enterprise headquarters locations was quite frequently present in research, but not explicitly as the main subject (Lisowski and Wilk, 2002; Micek and Jarczewski, 
2006; Markowski and Stawasz, 2007). More specific works appearing after 1989 usually focused on selected cities, particularly Warsaw (Dziemianowicz, 2000; Rutkowska-Gurak, 2000; Śleszyński, 2002; Śleszyński, 2006) and Poznań (Tobolska, 2004), studies on the influence of single companies (Adamczak, 1994; Rachwał, 2001; Stryjakiewicz, 2005), as well as selected economic sectors or groups of functions (Wolaniuk, 1997; Misztal, 1998; Wilk, 2001; Śleszyński, 2003), or city-area transformations (Rutkowska-Gurak, 2000; Śleszyński, 2004).

The present paper is based on the selected study results presented in a monograph of the same title (Śleszyński, 2008), particularly the issues concerning the location of enterprises in 8 largest Polish cities. The main cognitive goal of the study was to recognise the spatial structure of large enterprises in major Polish cities, having virtually no previous knowledge of the subject (except for Warsaw). This specifically included identifying certain regularities connected with the location of particular internal city structures (city centre, external area) and diversification of businesses (line of activity, ownership, size).

The analyses scrutinised data from the Hoppenstedt Bonnier database providing detailed information on around 60 features connected with employment, organisational structure, ownership, revenues, as well as management. The database contains data about the largest companies in Poland in the following numbers: around 15,000 (marketing version) and 60,000 (basic version without personal data). On internal city research in Poland, the base has been used with reference to Warsaw (Śleszyński, 2002). Due to the data timeliness period (2004), the analysis is a kind of summary of changes in the location of enterprises that occurred in the largest Polish cities during the political, social and economic transformation after 1989.

That is, Hoppenstedt Bonnier database is the most thorough information source about commercial revenues concerning the biggest Polish companies, however some of these major companies are excluded. Moreover, not full financial data are included. Some cases show that this database has been fulfilled with other alternative sources, including some editions of Rzeczpospolita daily.

The spatial scope of the analyses was limited by choosing cities with the highest number of enterprises, and thus of greatest importance for business development. They were selected on the basis of the MEGA classification (Metropolitan European Growth Areas), identifying 8 such centres on the map of Poland (Tab. 1). They were: Warsaw, Szczecin, Trójmiasto (Gdańsk, Gdynia, Sopot), Poznań, Łódź, Wrocław, Katowice and Krakow. In this group, 6 centres are clearly monocentric, and 2 - polycentric (the Tricity, Katowice). Of the latter two, detailed location analysis was performed with respect to the urban area of Gdańsk, Gdynia and Sopot, whereas in the case of the Upper-Silesian conurbation, the analysis was limited to Katowice.

The study concerned the largest enterprises. They were chosen arbitrarily by selecting from the base the 10,000 largest companies in Poland according to their revenues from all lines of activity in 2004. The smallest entity reached the revenue of 15.6 million PLN (in current prices). 3810 (38.1\%) such entities were located in the 8 largest Polish cities. Their combined revenues amounted to 747 billion PLN, accounting for $46.1 \%$ of the total number 
of 10,000 largest businesses in the whole country, and $46.9 \%$ of the total revenues of all 3.3 million enterprises registered in Poland at that time.

Tab. 1. Basic data on enterprises under analysis according to urban centre (2004)

\begin{tabular}{|c|c|c|c|c|c|c|c|c|c|}
\hline \multirow{3}{*}{ City } & \multirow{2}{*}{\multicolumn{2}{|c|}{$\begin{array}{c}\text { Company } \\
\text { headquarters }\end{array}$}} & \multicolumn{5}{|c|}{ Revenues } & \multirow{2}{*}{\multicolumn{2}{|c|}{ Employment }} \\
\hline & & & \multicolumn{2}{|c|}{ value } & \multicolumn{3}{|c|}{$\begin{array}{l}\text { dominant or main ownership } \\
\text { structure }\end{array}$} & & \\
\hline & number & $\%$ & PLN bn & $\%$ & public & $\begin{array}{l}\text { private, } \\
\text { domestic }\end{array}$ & foreign & thousand & $\%$ \\
\hline Katowice & 192 & 5.0 & 62.9 & 8.4 & 37.5 & 37.7 & 24.8 & 217.4 & 12.2 \\
\hline Krakow & 363 & 9.5 & 51.3 & 6.9 & 8.1 & 45.0 & 46.9 & 134.3 & 7.6 \\
\hline Łódź & 243 & 6.4 & 25.1 & 3.4 & 40.2 & 38.8 & 21.0 & 80.0 & 4.5 \\
\hline Poznań & 366 & 9.6 & 52.2 & 7.0 & 13.1 & 33.2 & 53.7 & 97.1 & 5.5 \\
\hline Szczecin & 146 & 3.8 & 19.5 & 2.6 & 55.1 & 26.4 & 18.5 & 42.7 & 2.4 \\
\hline The Tricity & 358 & 9.4 & 40.8 & 5.5 & 8.4 & 75.8 & 15.7 & 101.7 & 5.7 \\
\hline Warsaw & 1,859 & 48.8 & 465.7 & 62.3 & 15.1 & 22.7 & 62.2 & 999.8 & 56.3 \\
\hline Wrocław & 283 & 7.4 & 29.7 & 4.0 & 10.6 & 54.1 & 35.3 & 102.8 & 5.8 \\
\hline Total & 3810 & 100.0 & 747.2 & 100.0 & 17.7 & 31.0 & 51.3 & 1.775 .8 & 100.0 \\
\hline
\end{tabular}

Source: own calculation based on Hoppenstedt Bonnier data

\section{CHANGES IN LOCATION FACTORS DURING TRANSFORMATION}

One may currently list a few groups of factors related to market mechanisms in the location of businesses in urbanised areas in Poland. A certain part of entrepreneurial activities are located primarily in densely populated areas, ensuring better access to the market. This model particularly aptly describes less-specialised individual services, which has been shown on the example of Warsaw in the study by W. Wilk (2001). More specialised services, e.g. ones related to management, are characterised by concentration in central city areas, due to high availability and prestige (Śleszyński, 2004). As far as industry is concerned, on the other hand, the most important features are access to labour resources, logistic and transport conditions connected with suppliers and receivers, and environmental aspects (Misztal, 1998). In any case, the location of business is fundamentally based on the maximisation of efficiency defined in terms of revenues and profits of an enterprise, as well as its image and prestige. The structures of enterprise distribution may thus be explained using classic location theories. In the case of internal urban structure, special focus is placed on the concentration of enterprise headquarters within the Central Business District (CBD).

The process whereby the city centre becomes the decision-making environment was described by M. Castells (1972). The phenomenon is said to arise from the intention to mark a function by occupying space - or emphasise ownership. The other reason is efficiency, connected with the existence of formal and informal networks of relations: official (in the sense of contacts with public institutions, e.g. state administration), business-like, and even 
personal - that is because the time of communication needs to be relatively close in spatial terms. Consequently, the functional specialisation of the centre stems from "stronger connection between decision-making techniques and the existence of information and innovation environment and a chain of non-reproducible mutual relations". M. Castells thus concludes that a Central Business District (CBD) is a logical consequence of the process of technocratisation of highly-industrialised societies.

One might suspect that the emergence of CBDs in the Polish reality is connected to essentially the same location factors (economic, logistic and prestige-based), but there is a fundamental diversification of their hierarchy and importance. For example, one may imagine a situation where - due to political and social transformations - the prestige factor has been radically re-evaluated, and is now interpreted as the location of company headquarters in the proximity of characteristic objects, e.g. ideological symbols. Another differentiation factor is the said ownership status. The basic differences may be presented as follows:

Economic factors. The influence of land rent is not as strong in Poland as in countries with well-established market economies. The reason is surely a higher land supply, resulting from the extensiveness of development. Warsaw is an exception here, with very limited land resources due to unresolved ownership issues. Agglomerative benefits resulting from gathering a large number of entities in the same area are similar. For obvious reasons, Poland is also not a good place for spectacular and cost-consuming investment projects involving radical transformations of districts or even street quarters;

L ogistic factors. The distinctiveness of Polish cities stems from their usually much poorer transport infrastructure. It results in the absence of more significant processes of dispersion of business headquarters, as well as functional specialisation, observed not only in countries with long free-market history, but also in emerging economies, e.g. in Asia (cf. e.g. Nahm, 1999);

Prestige factors. In Polish cities, with their short history of the free-market economy, and a peculiar combination of economic, ownership-related and social factors, urban CBDs and management locations not always emerge in areas of higher social status. It seems, however, that it is a more complex issue, as the very emergence of areas of higher and lower social and residential status after 1989 has been subject to different factors than in the West;

$\mathrm{Natural}$ factors. For reasons described in a) above (shortage of funds), and due to civilisation and culture differences, in Poland much less attention is paid to development in urbanistic and aesthetic terms, including incorporating architectural structures and urban axes into the existing urban systems, as well as topography, hydrography etc.

Spatial structure of economic control functions in LARgest Polish cities

In 2004, of 3800 companies operating in Poland, each with annual revenues over 15.6 million PLN, as many as 1800 (48.8\%) were based in Warsaw. The enterprises were primarily concentrated in the city centre (Fig. 1). It was the location of the headquarters of nearly 
all the largest companies, such as Telekomunikacja Polska, PZU and PZU Życie, and Polskie Sieci Elektroenergetyczne - currently Polska Grupa Energetyczna. The second, much smaller area of business concentration was South Służewiec (e.g. Philip Morris, Real).
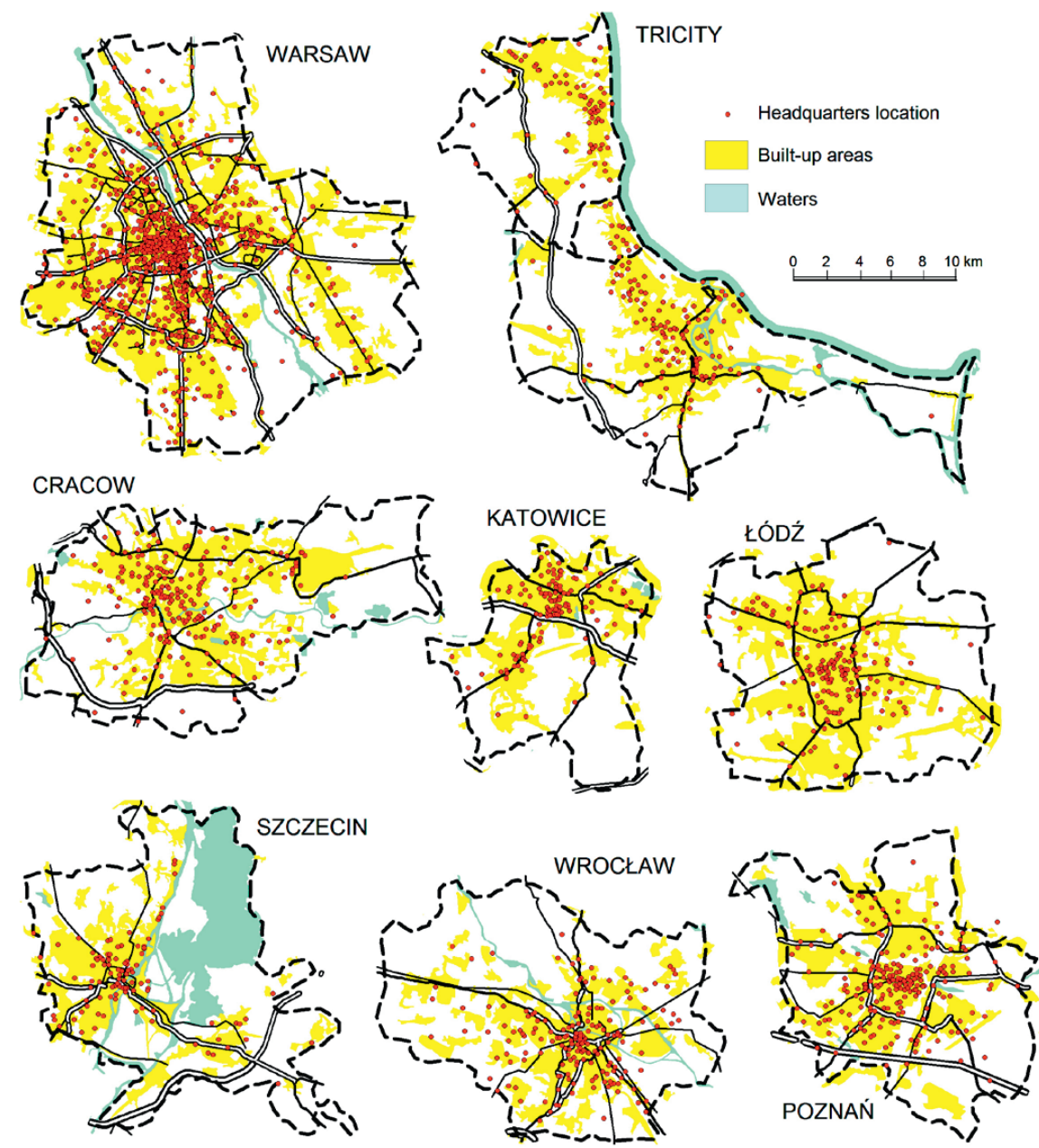

Fig. 1. Location of company management headquarters (revenues above 15.6 million PLN in 2004) in the largest Polish cities

Source: own elaboration based on Hoppenstedt Bonnier data

192 headquarters of businesses generating a revenue of 15.6 million PLN or higher were identified in Katowice. The headquarters were located in few areas, the major one being the city centre. It was where the main offices of coal-trade holdings and coal and coke import and export headquarters were located. A significant number of companies were also based north of the city's functional centre. Moreover, in the north-east part of the city, the Szopienice 
Steelworks was located. The main office of Getin Bank was located in complete detachment from other company headquarters.

In Krakow, the study found 363 enterprises with a combined revenue of 51.3 billion PLN in 2004. The great majority of company offices were located on the left bank of the Vistula river, mostly in the city centre, including the Old Town Square (e.g. Bank BPH, Krakowski Bank Spółdzielczy). Trade chains headquarters were located in some distance from the oldest part of the city (Ahold Polska, Slovnaft Polska), and in the outer zone. Similarly, the head office of Tesco Polska was located on the right bank of the Vistula. In the southern outskirts, near the route to Myślenice, the IT company Delphi Poland was located. Huta im. T. Sendzimira (Sendzimir Steelworks, the second largest plant of its kind in Poland) was not taken into account, as in 2004 it had formally become a branch of the Polskie Huty Stali / ISPAT Polska Stal group, and has subsequently been sold to a foreign owner, LNM Holdings (together with Mittal Steel Poland, and in 2007 to ArcelorMittal Poland).

In Łódź, there were 244 companies with individual revenues exceeding 15.6 million PLN at the end of 2004. Of this number, only three reached the revenues above 1 billion PLN: BOT Górnictwo i Energetyka (PLN 6.8 bn), Polska Grupa Farmaceutyczna (PLN 2.3 bn) and Bank Przemysłowy (PLN 1.0 bn). Most company headquarters were located in the centre of Łódź. Enterprise concentrations were also identified in other parts of the city, i.e. in western Bałuty (e.g. Rossmann Supermarkety Drogeryjne Polska, Polska Grupa Farmaceutyczna), as well as on the border of Widzew and Górna, where large industrial plants were located (Merloni Indesit Polska, heat processing plant).

In Poznań, the number of entities qualifying for analysis was 366, ten of which generated revenues of more than 1 billion PLN each (e.g. Volkswagen Poznań - 7.6 billion PLN, Enea - 4.3 billion PLN, Kompania Piwowarska - 2.7 billion PLN, Selgros - 2.2 billion PLN). Poznań was the second-ranking (after Warsaw) centre of concentration of economic control functions in Poland, though its advantage over the other cities was minor. The Poznań city centre gathered the majority of enterprises and their revenues, including the headquarters of Enea, Wielkopolska Spółka Gazownictwa, Żabka Polska, KDWT, and Dom Maklerski BZ WBK. Further away from the centre, in essentially all directions, the offices of other companies were located, such as Volkswagen Poznań and its affiliate Škoda Polska (near the route to Warsaw), H. Cegielski-Poznań (in the south), PGF Cefarm-Poznań (in the west), or Dalgety Agra Polska (in the north). At the western fringe of the city, the headquarters of the wholesale company Eurocash were located.

Szczecin was home for 146 enterprises with revenues over 15.6 million PLN and trade turnover over 19.5 billion PLN. From this point of view, the city ranked last among the eight centres under analysis. Only four companies reported revenues over 1 billion PLN in 2004: Państwowe Przedsiębiorstwo Użyteczności Publicznej Poczta Polska - Urząd Przewozu Poczty (PLN 6.1 bn), Swedwood Poland (PLN 1.7 bn), Stocznia Szczecińska Nowa (PLN 1.5 bn) and Polska Żegluga Morska (PLN 1.0 bn). The great majority of firms were headquartered in the city centre. Of the larger entities, only the industrial company Swedwood Poland was located in a certain distance from the centre. Only a few enterprises had their offices on the right bank of the Oder. 
In the three urban centres of the Tricity (Gdańsk, Gdynia and Sopot), 341 companies with revenues over 15.6 million PLN were identified, with a combined turnover of 40 billion PLN. The largest ones were Grupa Lotos (PLN 10.3 bn), Lotos Partner (PLN 3.2 bn), GE Money Bank (PLN 1.4 bn) and Sopockie Towarzystwo Ubezpieczeń Ergo Hestia (PLN 1.0 bn). The Tricity has a characteristic distribution of the companies. They are gathered around individual city centres in the agglomeration, but there also is a clear line of increased location intensity between them. It is connected with the spatial and functional system of the Tricity.

283 enterprises with combined revenues worth 29.7 billion PLN were found in Wrocław. Only three of them reached a turnover above 1 billion PLN: Bank Zachodni WBK (PLN 2.6 bn), Volvo Polska (PLN 1.4 bn) and Lukas Bank (PLN 1.0 bn). Company headquarters were primarily located in the city centre. However, a few larger firms, mostly involving foreign capital, had chosen locations in a certain distance from the centre. It mostly concerned companies from the industrial sector, whose management offices were situated next to production facilities (Wrozamet, Polar, Volvo Polska). Similarly, trade businesses were located either in the external zone (PGF Urtica, Ordipol), or at the city outskirts (Incom).

\section{REGULARITIES OF DISTRIBUTION IN RELATION TO THE CENTRAL POINT}

The location of a number of headquarters in relation to the central point reveals characteristic regularities. In most general terms, it is a proportional drop in the value of individual variables as the distance from this point increases (Fig. 2). What is peculiar, it concerns Warsaw to a lesser degree than other cities under analysis.

An almost "perfect" trend of the curves (in accordance with the logistic model) is particularly characteristic of Łódź, Katowice, Krakow, the Tricity and Wrocław, and slightly less of Poznań and Szczecin.

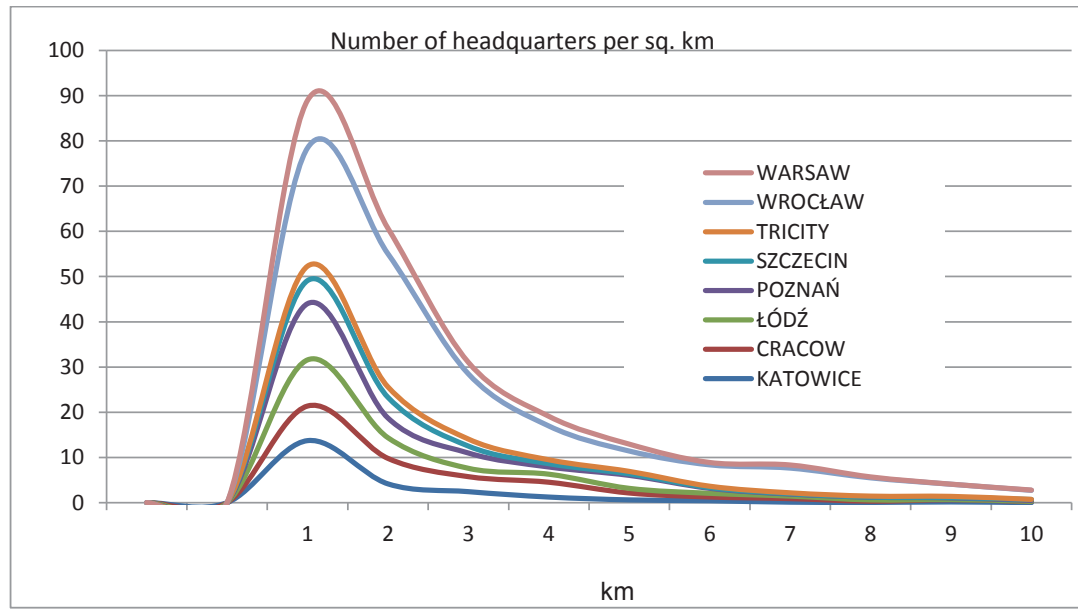

Fig. 2. The number of company headquarters in 1-km concentric zones from the central point Source: own elaboration based on Hoppenstedt Bonnier data 
In the case of trade volume, the alignment with logistic curves was much poorer than for the number of entities. In nearly all distributions under study, there was a regularity of revenues decreasing in proportion to the growing distance from central points (Fig. 3). The only difference was that Warsaw was characterised by a more proportional drop in the revenues than in the case of other cities. It turns out that in the smaller centres, a considerable amount of revenues is concentrated in the radius of one kilometre from the central point. The regularity is particularly observed in Łódź, Katowice and Wrocław, and to a lesser extent in Poznań. In Krakow, the Tricity and Szczecin, the revenue distribution is more equal, with the dominant not necessarily placed in the closest concentric circle.

Analysis of ownership structure reveals further clear regularities. Managements of state-owned companies are more often located near the central point (Fig. 4). Again, it is most distinctive in the case of cities other than the capital. The most frequent situation is that of a high concentration relatively close to the central point (Łódź, Katowice, Poznań, Szczecin). And again, in Warsaw it was different, as the revenues initially grew, reaching the dominant at the distance of $3 \mathrm{~km}$ from the central point. This is because some public companies are not located near the city hall, but rather near other institutions whose central functions would have been more adequate in studying economic control functions of the capital (the Parliament, the President, the Prime Minister). More even distributions can be found in the home and foreign private sectors, but not in all of them. The dispersion of revenues in relation to central points is particularly noticeable in the histograms concerning Poznań, Krakow and Łódź.

Distinguishable regularities were typical of various lines of business. The study only included some of them, in adequate numbers (Fig. 5). In the case of industrial companies, the analysis revealed no relationship between revenue and distance from the central point (sometimes the revenue even increased further away from this point). This situation is due to the fact that some managements of industrial entities were located at production facilities, definitely outside city centres. The histograms concerning retail trade are also less regular. In a few cases, the dominant fell on the second concentric circle (1-2 km, e.g. Warsaw, Poznań, Szczecin), though the regularities are still greater than in the industry sector.

The most regular distributions occurred in the sector of high-order services, as presented in the figures under the financial business category (section $\mathrm{J}$ of the Polish Classification of Activities), and professional services (sections $\mathrm{K}, \mathrm{M}, \mathrm{N}$ and part of $\mathrm{O}$ ). Especially in the case of the financial sector, revenues were concentrated close to the central points. The alignment of distribution curves with logistic functions was highest for professional services, usually exceeding the alignment ratio of 0.95 .

The analyses clearly point to regularities connected with enterprise structure. One may notice more frequent location of management headquarters of companies with specific features regarding ownership, size and type, and it can be determined using the function of distance from central points that are city authorities' offices, designating mathematical city centres. 
KATOWICE

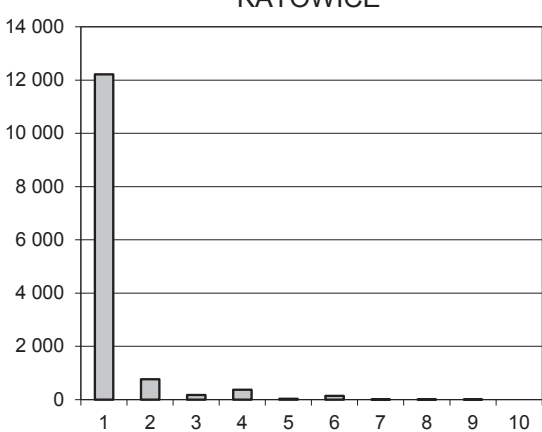

ŁÓDŹ

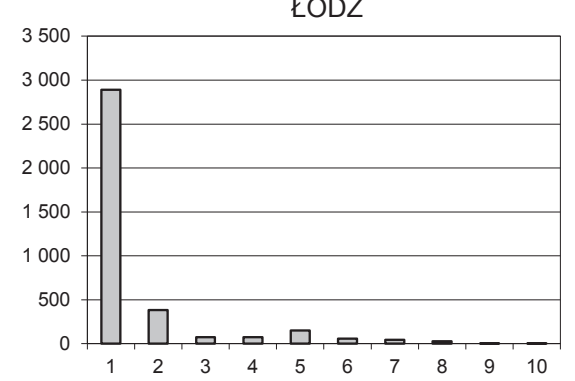

SZCZECIN

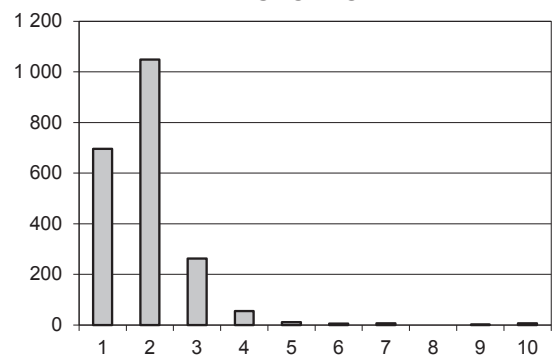

WARSAW

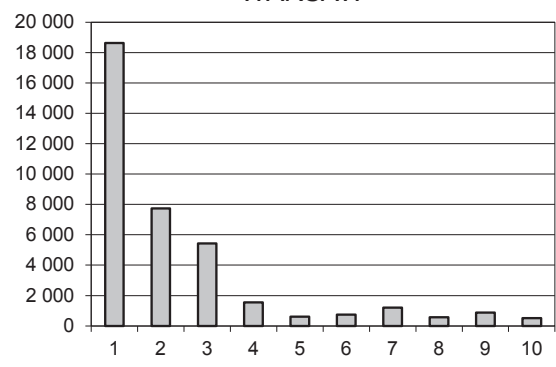



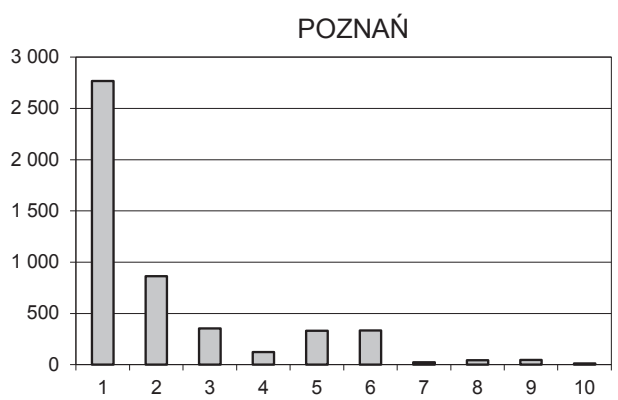

TRICITY

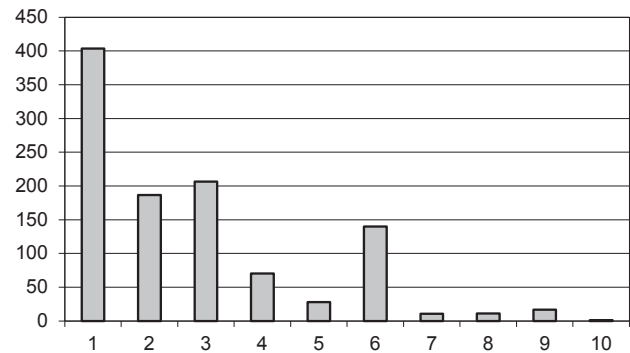

WROCŁAW

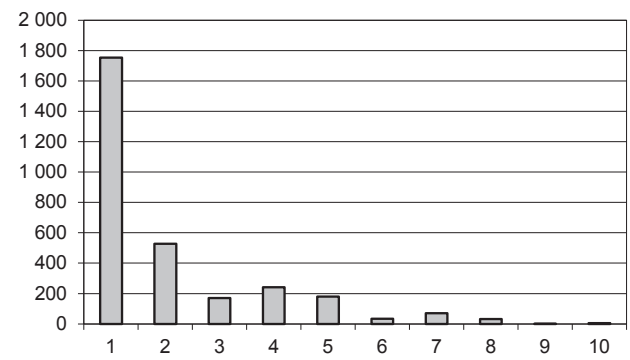

Fig. 3. Total revenues of companies in 1-km concentric zones from the central point Source: own elaboration based on Hoppenstedt Bonnier data 

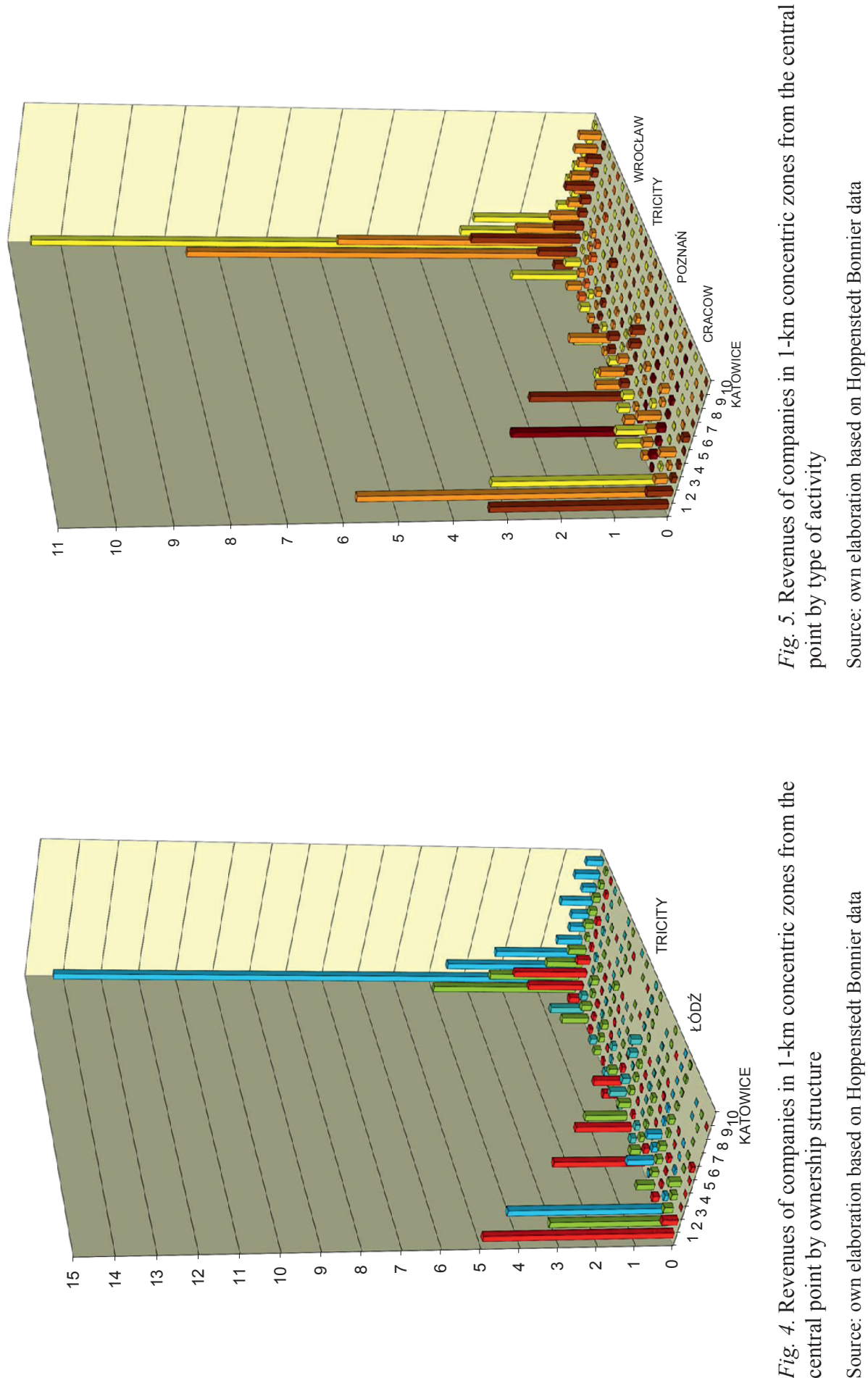
The analysis helped to determine that the extreme values of concentration factors were usually obtained for Warsaw at one end, and for Łódź, Szczecin and Katowice at the other. More diversified were the indicators referring to individual ownership types. Apparently, the most concentrated distribution occured in the case of the headquarters of publicly-owned companies (state and municipal), less so in the case of privately-owned firms, and least - in foreign ones. Nonetheless, the latter case does not signify dispersion, as the values were still relatively high.

It seems thus that Warsaw's advantage in the values of individual indicators is generally considerable, suggesting an advanced stage of establishment of the decision-making centre as compared to other Polish metropolies (which is also visible in terms of architecture). Moreover, the analyses have also led to certain conclusions about the character of functional urban centres. They can be tentatively (without any empirically-specific classification) grouped into three categories (the following list does not include the Tricity as a polycentric agglomeration, but does take into account Katowice, as it was analysed separately from other cities in the conurbation):

1. Warsaw - with the most developed and densest (in Poland) network of managements and their prospective links, providing grounds for the thesis about the emergence of a CBDtype centre (city);

2. Poznań, Krakow, Wrocław and Katowice - as locations characterised by a similar structure of "management space" but not enough to formulate the thesis about the emergence of an urban city;

3. Szczecin and Łódź - with least developed economic control functions and management space.

The above conclusions should be treated cautiously, as they were formed without comparison to a "model" - very difficult to define, if at all possible. The main problem is that one cannot precisely identify the moment in the development of economic urban functions and their concentration in the central area when a CBD (city) appears. As the analyses have shown, there are no real regularities in the diversification of the indicators, and the only city where such thesis seems justified is the state capital. Therefore, perhaps the essence of a city centre is determined by more individual features, connected with both the city's history, tradition and culture, local topography and morphology, and the urbanistic system itself.

The scope of the studies did not include research conducted over time, which prevented tracing change trends, neither with respect to enterprise location itself, nor the company structures and their networks of links. It is probable that there occur some specific moments when the values of individual indicators are subject to a noticeable change. The problem requires further and more detailed studies.

\section{LOCATION MODELS}

Further considerations explaining the identification of regularities in location distributions can be based on mathematical premises. First, one needs to formulate certain general model assumptions. It is necessary to make a generalisation that the location of company 
headquarters results from the maximisation of efficiency in terms of various groups of factors. Among them, one may list operational costs, prestige related to the location with reference to the city centre or the city's characteristic objects and spatial accessibility to prospective clients, as well as other enterprises and institutions, i.e. actually, the proximity to other headquarters.

The moments when indicators of company headquarters occurrence per unit of area reach threshold points are very characteristic for many types of activities. In the case of concentration of economic entities, a change in the curve trend may be interpreted as a change in location factors, or "breaking" the location point. This is quite an important assertion that might be of significance in explaining the process of emergence of a decision-making centre. An abrupt change in the curve trends means that it is possible to determine a place with both advantages and disadvantages of location. The advantage area is approximately the functional city centre, concentrating a high number of enterprises. Most importantly, however, is that in the case of some cities, it is possible to mathematically determine the threshold values above and below which locating company headquarters is or is not effective. Therefore, in order for a decision-making centre to appear, such as the one described by M. Castellsa (1972), it is necessary that a particular "critical mass" is reached, ensuring the development of managerial functions in a specific area of the city, usually corresponding to the morphological city centre.

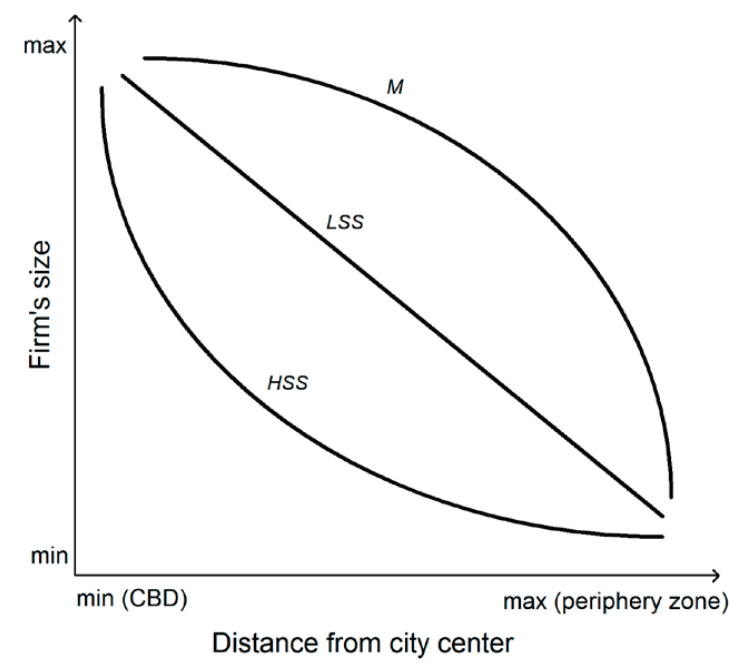

Fig. 6. Model of enterprise headquarters location in the spatial structure of the city. $\mathrm{M}$ - manufacturing, LSS - low specialized services, HSS - high specialized services

Source: own elaboration

Next, one may make certain generalisations stated in the form of regularities, laws or principles of business location in cities. They are synthetically presented in Figure 6. They are as follows: 
The size principle. The larger the enterprise, the more often its headquarters are located in a place occupying a higher position in the functional hierarchy, especially in a city centre;

The activity principle. The more advanced the sector of the economy, the more often company headquarters are located in places more important from the point of view of a city's functional structure, thus - as in the case of the largest enterprises - in the centre.

The ownership principle. Capital by nature (similarity) chooses locations as follows: public - closer to administrative authority offices, private - according to market potential, foreign - indirectly, usually depending on the company size and type of activity (see the two previous principles).

\section{Conclusions}

In the largest Polish cities, there is a spatial concentration of enterprise management headquarters, whereby businesses tend to preselect (choose more frequently) the functional centres as their location. This concentration is most significant in the case of the largest enterprises, the public sector and more advanced businesses, particularly high-order services. The location of large company headquarters, as well as their mutual connections, performs one of the key roles (or even the most important one) in the development of Central Business Districts in Polish cities during transformation.

There occurs a convergence of the headquarters location model. The location models tend to converge as the company size increases and its technological and organisational features become more advanced. And conversely, the differences increase as the activities become more simple and the companies get smaller.

Spatial distributions of enterprise headquarters according to their distance from the city centre generally tend to be of functional nature, describable using exponential and logistic models. It provides grounds for the statement that the location of company headquarters in the spatial structure of the largest Polish urban centres has become adjusted to market forces, in accordance with the monocentric model. One may further assume that in terms of the location of enterprise headquarters, the phase of economic transformation in the structure of these cities has been completed.

In spatial distributions of company headquarters analysed in relation to their distance from the centre, one may identify characteristic changes in the inclination of the curves at the so-called "points of tilt". Therefore, it is possible to mathematically determine the threshold values above and below which locating company headquarters is or is not effective. In order for a decision-making centre to emerge, it is probably necessary that a certain "critical mass" is reached, ensuring the development of managerial functions. Depending on this "critical mass", it is also possible to determine a place displaying location advantages and disadvantages. The area of highest advantages is the Central Business District (CBD). 
Detailed distributions of the number and revenues of businesses according to type of activity revealed a certain irregularity of the distribution models (to the least extent in Warsaw, and also slightly less in Poznań, Wrocław and Krakow) suggesting a spatial chaos, but at the same time, possibilities for further ordering of the management space structure. In other words, if one assumes equifinality of internal city structures, interpreted as reaching a point of equilibrium, one may expect that decision-making centres will still keep evolving quite intensely, especially in smaller cities.

Strong concentration of companies from the public sector can be explained with the similarity to location in relation to public administration offices, which may stem from both the inertia of spatial structure of economic management, and from new factors connected with the efficiency of location in the proximity of administrative and political authorities. On the other hand, the good alignment of distributions of the headquarters of domestic private enterprises may be put down to the knowledge of local conditions allowing the adjustment to various elements of a city's spatial structure, thus ensuring location effectiveness.

Certain symptoms of dispersion among the headquarters of foreign entities may be due to the lack of knowledge of the local conditions, preventing them from finding the most advantageous position in the existing spatial structures, but also to differences in location factors connected with the necessity of better adjustment to the existing conditions, such as improving transport accessibility (e.g. to the airport) or reducing operational costs (e.g. through negotiating lower rent).

The regularities identified in the analysis are also indicative of a generally ordered economic structure of the city. The distributions of individual enterprises in terms of the activity structure and the number of employees are both of hierarchical (sometimes leap-based) and liquid nature (the latter referring to the land rent model). This arrangement thus invokes the central place theory in which higher-order (more specialised) types of activity are located at nodes, while the intensity itself refers to the land rent model.

What is particularly worth identifying is the main factor determining the distribution of enterprise locations: be it the said hierarchism, nodality and the resulting division of space into smaller functional units, or rather the land rent gradient, or perhaps consumer behaviour. It is even more important, that the economic structure of Warsaw has somewhat re-built itself anew after 1989, which justifies the purposefulness of comparisons to the spatial structure of cities at earlier development stages. One might consider studying the relationships in terms of distance from the city centre, district centres, or transport corridors, as well as some comparative works. In summary, it opens up broad possibilities of further research.

\section{References}

Castells, M. (1972). La question Urbaine. Paris: François Maspero.

Domański, B. (1997). Industrial control over the socialist town. Benevolence or exploitation? Westport: Praeger.

Dziemianowicz, D. (2000). Warszawskie przedsiębiorstwa w procesie globalizacji. In: A. Kukliński, J. Kołodziejski, T. Markowski, W. Dziemianowicz (eds.), Globalizacja polskich metropolii, 
Euroreg - Europejski Instytut Rozwoju Regionalnego i Lokalnego Uniwersytetu Warszawskiego. Warszawa: Oficyna Wydawnicza "Rewasz", 282-311.

Lisowski, A., Wilk, W. (2002). The changing of spatial distribution of services in Warsaw. European Urban and Regional Studies, 9(1), 81-89.

Markowski, T., Stawasz, D. (eds.) (2007). Rewitalizacja a rozwój funkcji metropolitalnych miasta Łodzi. Łódź: Wydawnictwo Uniwersytetu Łódzkiego.

Micek, G., Jarczewski, W. (2003). Krakowska przestrzeń biurowa. Kraków: Instytut Geografii i Gospodarki Przestrzennej UJ.

Misztal, S. (1998). Przekształcenia struktury przemysłu Warszawy. Atlas Warszawy, 8. Warszawa: IGiPZ PAN.

Nahm, K.-B. (1999). Downtown office location dynamics and transformation of central Seoul, Korea. GeoJournal, 49(3), 289-299.

Rachwał, T. (2000). Zmiany funkcjonowania Zakładów Przemysłu Cukierniczego „San” S.A. w Jarosławiu pod wpływem inwestycji zagranicznych. In: Z. Zioło (ed.), Działalność człowieka i jego środowisko. Kraków: Wydawnictwo Naukowe AP, 323-336.

Rachwał, T. (2001). Funkcjonowanie Krakowskich Zakładów Elektronicznych „TELPOD”w świetle przemian w polskim przemyśle elektronicznym. In: Z. Zioło (ed.), Problemy przemian struktur przemysłowych w procesie wdrażania regut gospodarki rynkowej. Prace Komisji Geografii Przemystu Polskiego Towarzystwa Geograficznego, 3, 167-180.

Rutkowska-Gurak, A. (2000). Miejski obszar przemysłowy jako środowisko lokalizacji firm (na przykładzie Stużewca Przemystowego). Warszawa: Monografie i Opracowania, Szkoła Główna Handlowa.

Stryjakiewicz, T. (ed.) (2005). Impact of foreign investors on regional and local development: the case of GlaxoSmithKline Pharmaceuticals S.A. in Poznań. Poznań: Bogucki Wydawnictwo Naukowe.

Śleszyński, P. (2002). Struktura i koncentracja przestrzenna siedzib ważniejszych przedsiębiorstw w Warszawie w 1999 r. In: Z. Zioło (ed.), Problemy transformacji struktur przemystowych. Prace Komisji Geografii Przemystu Polskiego Towarzystwa Geograficznego, 4, 89-114.

Śleszyński, P. (2003). Funkcje metropolitalne Warszawy - zarys problematyki. In: I. Jażdżewska (ed.), Funkcje metropolitalne i ich rola w organizacji przestrzeni. XVI Konwersatorium Wiedzy $o$ Mieście. Łódź: Katedra Geografii Miast i Turyzmu UŁ, Komisja Geografii Osadnictwa i Ludności PTG, Łódzkie Towarzystwo Naukowe, 119-134.

Śleszyński, P. (2004). Kształtowanie się zachodniej części centrum Warszawy. Prace Geograficzne, 196. Warszawa: IGiPZ PAN.

Śleszyński, P. (2006). Przedsiębiorstwa w przestrzeni Warszawy. Atlas Warszawy, 9. Warszawa: IGiPZ PAN.

Śleszyński, P. (2008). Duże przedsiębiorstwa w strukturze przestrzennej największych polskich miast. Prace Geograficzne, 217. Warszawa: IGiPZ PAN.

Tobolska, A. (2004). Zmiany własnościowe i organizacyjno-ekonomiczne w wybranych dużych przedsiębiorstwach przemystowych Poznania w okresie transformacji. Poznań: Bogucki Wydawnictwo Naukowe.

Węcławowicz, G. (1996). Contemporary Poland. Space and Society. London: Routledge.

Wilk, W. (2001). Czynniki lokalizacji i rozmieszczenie wybranych ustug $w$ Warszawie. Warszawa: Wydział Geografii i Studiów Regionalnych UW.

Wolaniuk, A. (1997). Funkcje metropolitalne Łodzi i ich rola w organizacji przestrzennej. Szlakami Nauki, 25. Łódź: Łódzkie Towarzystwo Naukowe.

Przemysław Śleszyński (born 1973), is a professor at the Institute of Geography and Spatial Organization of Polish Academy of Sciences. He is a scientist in economic, social and political geography and spatial economy. He is an author and a co-author of about 300 publications (including above 20 monographs) from this field of interest. He is an expert in the spatial development and the spatial planning, especially locations concerning issues and the social-economic and regional development. $\mathrm{He}$ led or participated in about 100 projects for government institutions, self-government and of the private 
sector. He is a member of the Polish Geographical Society and a member of the Society of Polish Town-Planners. For more detailed information please visit the website: http://www.igipz.pan.pl/osoba/ show/przemyslaw sleszynski.html

\section{Adres/address:}

Polish Academy of Sciences

Institute of Geography and Spatial Organization

ul. Twarda 51/55, 00-818 Warsaw, Poland

e-mail: psleszyn@twarda.pan.pl 